\title{
骨のエンドミル加エにおける切削温度と冷却効果 *
}

\author{
杉 田直 彦** 光 石 衛** \\ Cutting Temperature and Cooling Effects in End Milling of Bone \\ Naohiko SUGITA and Mamoru MITSUISHI
}

\begin{abstract}
In this paper, the measurement of cutting temperature associated with the bone cutting robot have been investigated for cortical bone. The temperature distribution on cutting edge just after finishing of the cutting was observed by a thermography near the cutting area, and the internal thermal distribution was also measured using the thermocouple buried near surface of the workpiece. The experimental results are summarized measured as follows. (1)The cutting temperature in up-cutting was higher than that in down-cutting. (2)When the cutting speed was increased from $7.85 \mathrm{~m} / \mathrm{min}$ to 62.8 $\mathrm{m} / \mathrm{min}$, the cutting temperature was risen by about $10 \mathrm{deg}$.C, although the cutting force was not almost changed. (3)The cutting temperature could be lowered to about 30 deg.C using the cooled tool and bone at -5 deg.C. (4)As the result, it is suggested that the necrosis of bone tissue and cell would be avoided under this lowered cutting temperature.
\end{abstract}

Key words: cutting temperature, cortical bone, end milling

\section{1. 緒言}

筆者らは，骨の切除加工を目的とした人工膝関節置換術支 援骨切除装置 ${ }^{1)}$ を開発中であるが, そこで注目しなければな らない事項の一つが骨の組織や細胞に対する切削温度の影響 である. Krause ${ }^{2)} ら は, 50{ }^{\circ} \mathrm{C}$ を越えると骨細胞が壊死し始 め, $70^{\circ} \mathrm{C}$ 以上では骨細胞の回復は不能状態になると述べて いる.これは, 骨細胞に限度以上の熱が加わると, 酵素や蛋 白質が変質して細胞が生化学的損傷を受けた状態になるため としている．ところが，その一方で固体状態のコラーゲンは

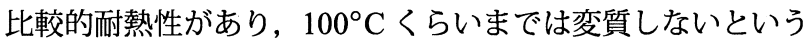
説もある ${ }^{3)}$.

これまでに報告された骨切削における温度測定例として, 前出の $\mathrm{Krause}^{2)}$ らのボーンソーによるものがある. そこで は, $170 〜 259{ }^{\circ} \mathrm{C}$ だった温度が $25^{\circ} \mathrm{C}$ の食塩水を $60 \mathrm{ml} / \mathrm{min}$ の流量で注水することにより $31 \sim 38{ }^{\circ} \mathrm{C}$ にまで低下したと報 告している. そして, 生体の皮質骨中の血流は間違いなく切 削中の骨組織を冷却する効果があるはずだ，という興味深い 考察もしている. また, Malvisi $\zeta^{4)}$ は, 5 自由度の工具保持 アームに 2.5 12.5 mm 径のミリングカッタを取り付けて, 人 骨の大腿骨遠位端と脛骨近位端を切削し, 表面から $1 \mathrm{~mm}$ 下 の温度を測定した結果, 冷却なしで $46^{\circ} \mathrm{C}$ の温度を測定して おり, 切削温度は骨の密度や測定場所によって多少異なるこ とも報告している.

ところで, これらに対して, 前述の筆者らの人工膝関節置 換術支援骨切除装置 ${ }^{1)}$ ではエンドミルを骨切除工具として用 いており, しかも, 加工能率を上げるために工具を高速回転 させることから, 高い切削温度が予測される. したがって, もしその温度が高く, それを低く抑えることができない限り， この骨切除装置を用いて実用的に人工関節手術の中で骨の工 ンドミル加工を行うことは不可能ということになる．そのた

* 原稿受付 平成 17 年 5 月 26 日

** 正 会 員 東京大学大学院（東京都文京区本郷 7-3-1）
めに本研究では基礎的な切削実験における骨の切削温度測定 を行い, その温度が骨細胞に有害だとしたら, どのような切 削環境を設定すれば実用的に骨切削が可能であるかという問 題を解決する手段を見出したいと考えている.

具体的には, 近接レンズを装着したサーモグラフィーを切 削部に近接して, 切削直後の切れ刃とその周辺の工具表面温 度分布を観測するとともに, 被削材内部の切削点近傍に埋め 込んだ熱電対で被削材内部の温度分布を求めることから切削 点の温度を推定し, 両者の比較から骨切削の温度を知ろうと 試みた. また, それとともに, 切削熱による骨細胞の劣化を 防止するための加工環境の冷却効果についても述べる.

\section{2. ロボットを用いた骨切除加工における切削温度測定例}

最初に, 前述の人工膝関節置換術支援骨切除装置を用いた 人体標本 (人骨) 切除実験において, 切削温度がどの程度にな るかについて, サーモグラフィーで切除部位全体を観測し, 切削部の温度経過を観察した.

切削の様子と実験条件を図 1 に, また, その観測結果を図 2 に示す. この場合には, 膝関節の大腿骨前面部を切削して いるが, この部位では約 $50 \mathrm{~mm}$ 幅の海綿骨部に対して両端 に約 $1 \mathrm{~mm}$ の厚みの皮質骨部が存在する構造となっている. 切削実験は乾式と湿式で行った. 湿式の場合, $4{ }^{\circ} \mathrm{C}$ に冷蔵保 存した生理食塩水を切削部に注水 $(150 \mathrm{ml} / \mathrm{min}) し て$, 冷却水 による切削環境の冷却効果を検討した. 図 2(a) は乾式切削を 行った場合で，(b) は冷却水を用いた場合を示している.

図 2(a)(b) ともに軟部組織における蓄熱の影響が見られる が, それでも工具先端部の温度は, 皮質骨部において最大と なり, (a) の場合約 $45^{\circ} \mathrm{C}$ であった. これに対して, 冷却水を 用いると (b) のように約 $35^{\circ} \mathrm{C}$ になった. このことより, 本 実験条件においては, 冷却水を用いると約 $10^{\circ} \mathrm{C}$ 温度を下げ る冷却効果が認められたので, 実際の手術における切削環境 冷却法の一つとなることが示唆された.

いずれにしても, この予備的な実験結果では, 前述で予測 したような工具の高速回転による高い切削温度とはならず, 


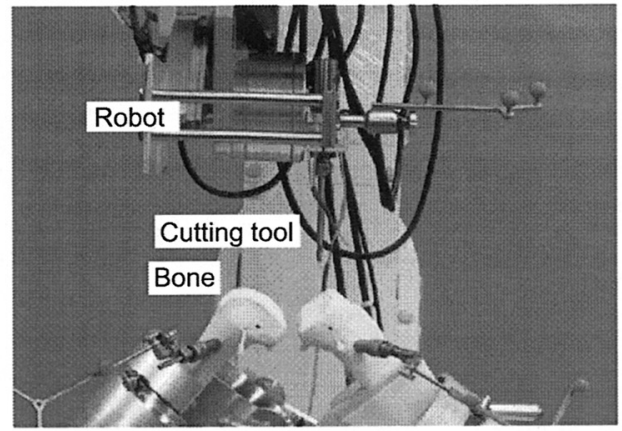

Fig.1 Cutting experiment, Cutting type: up cutting, Cutting speed: $\mathrm{V}=94.2 \mathrm{~m} / \mathrm{min}$, Rotational speed: 5000 rpm, Feed per tooth: $\mathrm{Ft}=0.02 \mathrm{~mm} /$ tooth, Axial depth of cut: $5 \mathrm{~mm}$, Radial depth of cut: $2 \mathrm{~mm}$, Cutting tool: $\phi 6$, square end mil, 3 flutes

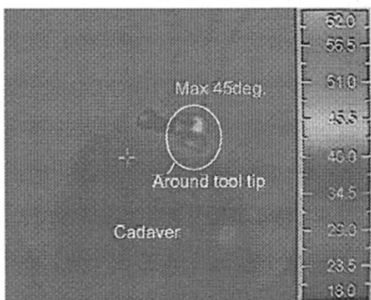

(a) Without coolant

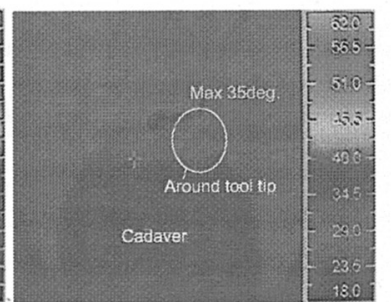

(b) With coolant
Fig.2 Thermographs in cadaver bone cutting

この程度の切削温度ならばこの骨切除装置を実用的に使え ることが暗示されたので, この実験結果を背景として, 切削 温度の高い皮質骨について，マシニングセンタを用いて骨の 基礎的な切削温度測定を各種の切削条件について行うととも に, 切削環境の冷却効果についても検討した.

\section{3. 実 験 方 法}

\section{1 マシニングセンタにおける温度測定システムの構成}

図 3 に切削温度測定の計測システムを示す．加工実験装置 は次の通りである. マシニングセンタ (森精機, Accumill4000) のテーブル上に 3 分力動力計 (キスラー, 9257B) を設置し, その上に切削温度測定試験片を取り付ける. そして主軸にエ ンドミル (不二越, 高速度鋼, スクエア, $\phi 10,2$ 枚刃, ねじ れ角 $30^{\circ}$, すくい角 $14^{\circ}$, 突き出し長さ $70 \mathrm{~mm}$ ) を取り付け, その外周刃でバイスで挟んだ試験片の側面を切削する.

温度測定は次の 2 つの方式で行った. その 1 つは, サーモ グラフィー (NEC 三栄, TH5104R) に近接拡大レンズ (NEC 三栄, TH51-377) を取り付けて切削部に接近し, 切削行程終 了直後の工具切れ刃部を拡大してサーモグラフを撮影する方 式である. 工具は高速度鋼で放射率が高くないので, 工具の 放射率を上げるために, 実験毎に耐熱黒色塗料を塗布したが, その状態での放射率は 0.98 であった. 当然, 切削による塗料 剥奪のために多少の放射率低下は避けられない.

第 2 は熱電対を用いる方法である. 後述の図 4 のように, 試験片内部の表層近くに熱電対を埋め込み, その熱電対の上 を切削する. エンドミルは決められた 1 刃送り量で切削す るので, 切れ刃が熱電対に近接すると, 1 刃が切削するごと に切削熱による熱起電力を熱電対に生じ温度として計測され る.このとき 1 回の切削で熱電対は切削により切断されるの で, 切れ刃が熱電対に近接した位置での温度が測定できるは ずである. 熱電対は $0.1 \mathrm{~mm}$ 径の銅一コンスタンタン線で, 0 $\sim 100{ }^{\circ} \mathrm{C}$ で検定した.

本実験では横フライス切削を行った. 皮質骨のオステオン 組織構造から代表的な切削方向として, 骨軸平行方向と骨軸

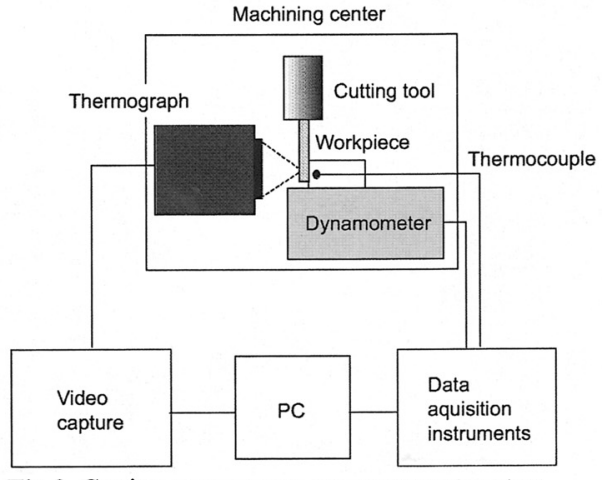

Fig.3 Cutting temperature measurement system

接線方向と骨軸断面方向の 3 通りが考えられるが, 骨軸接線 方向における切削の温度を測定した. これは, 人工膝関節置 換術では大腿骨の前面や後面あるいは脛骨関節面の切削の事 例に対応する.

切削条件は, 工具回転数 $250 \mathrm{rpm}(7.85 \mathrm{~m} / \mathrm{min}) \sim 5000$ $\mathrm{rpm}(157 \mathrm{~m} / \mathrm{min}), 1$ 刃送り量 $0.015 \sim 0.375 \mathrm{~mm} /$ tooth, 軸方向 切込 $5 \mathrm{~mm}$, 半径方向切込 $1 \mathrm{~mm}$ とし, 乾式にて実験を行った.

\section{2 切削温度測定試験片と熱電対の埋め込み}

切削温度測定に用いた骨は大腿骨の長管骨部を輪切りにし て採取したものである. 図 4 に示すように, リング状の皮 質骨を 2 つ割にして, 前述のようにその断面に $0.1 \mathrm{~mm}$ 径の 銅一コンスタンタン熱電対を骨表面下 $0.5 \mathrm{~mm}$ のところに埋 め込んだ後, 中空部に樹脂を充填して試験片全体を補強した。

次に, 熱的特性として皮質骨と高速度鋼の比熱と熱伝導率 を表 1 に示す ${ }^{5)}$. 骨の比熱は高速度鋼の約 3 倍であるが, 骨 の熱伝導率は低く，高速度鋼の $1 / 100$ 程度である.

\section{3 切削環境の冷却}

後述の 4.5 節で述べるように, 切削環境を冷却することが 切削温度にどのような影響をもたらすかを検討するため, 冷 却法として (a) 工具冷却, (b) 骨冷却, (c) 工具と骨冷却の 3 通 りの方法を検討した. そのとき具体的には必要な冷却時間だ けドライアイスを対象物に直接押し付けて冷却したが, 低温 脆性を避けるために工具が-10 ${ }^{\circ} \mathrm{C}$ 以下にならないように配慮 し, $-5^{\circ} \mathrm{C}$ 以上のところを切削開始温度とした.

図 5 は加工しないときの冷却した工具と骨の室温までの昇 温曲線である. 骨は冷却後そのまま室温中に放置して, 室温

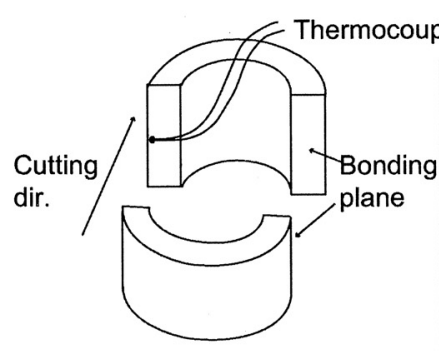

(a) Setting of thermocouple

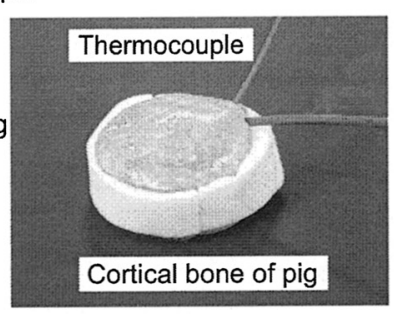

(b) Overview of workpiece
Fig.4 Workpiece for internal temperature measurement

Table1 Thermal properties of human bone and high speed steel

\begin{tabular}{ccc}
\hline Material & $\begin{array}{c}\text { Thermal conductivity } \\
{[\mathrm{W} / \mathrm{m} \cdot \mathrm{K}]}\end{array}$ & $\begin{array}{c}\text { Specific heat } \\
{[\mathrm{J} / \mathrm{kg} \cdot \mathrm{K}]}\end{array}$ \\
\hline Human bone $^{5)}$ & $0.16-0.34$ & $1140-2370$ \\
\hline High speed steel & $20-30$ & $400-900$ \\
\hline
\end{tabular}




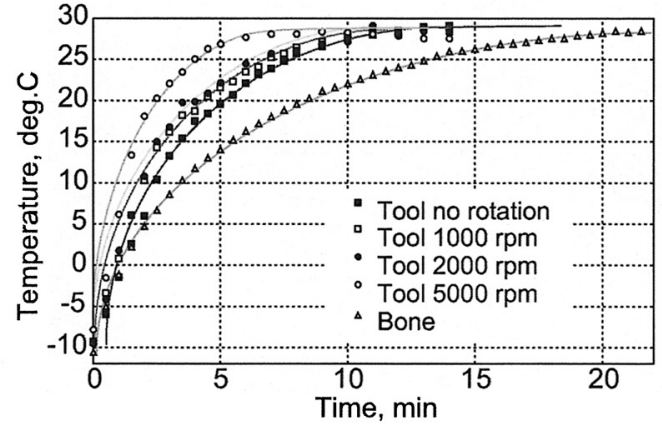

Fig.5 Temperature rising process of cooled bone and tool in atmosphere

までの温度回復過程を熱電対で測定した. 工具は回転数 0〜 $5000 \mathrm{rpm}$ のときの昇温をサーモグラフィーで観測した. 工具 回転数が高いほど昇温しやすいのは，主軸からの熱伝導と温 度勾配に依存した周囲からの熱流入のためと推察される.

実際の切削実験における 1 回の切削時間は試験片の送り速 度が最も遅い場合でも数秒以内なので, 図 5 の結果からする と，その時間内に骨や工具の温度が上昇することはほとんど 無視してもよいとみられる.

\section{4. 実験結果とその考察}

\section{1 切削温度とその分布}

図 6 は 1 枚のエンドミル切れ刃が切削行程を終了したとき に試験片から離脱した直後の切れ刃とその周辺の温度分布を サーモグラフィーで観測した例である. 白点線で示したライ ンが切削直後の切れ刃線上の温度であり, この切削条件で約 $45^{\circ} \mathrm{C}$ ないし約 $65^{\circ} \mathrm{C}$ の温度が観測された.

また, この切削直後の切れ刃の 1 つ前の切れ刃では, 約 35 ${ }^{\circ} \mathrm{C}$ にまで工具温度は低下しており，2 枚刃の場合には，この 切れ刃が次に切削を開始するまでに, 空冷によってほぼ室温 まで冷却していると推察できる。

この同じ切削過程で, サーモグラフィーによる観測に併行 して熱電対で温度計測したものが図 7 である.ここでは温度 計測に同期した切削抵抗も測定している．前述のように，熱 電対は被削材表面直下 $0.5 \mathrm{~mm}$ のところに埋められているの で, エンドミルの半径方向に $1 \mathrm{~mm}$ の切込を与えると, 1 回 の切削で熱電対は切断されることになる. また, 図 7 の温度 パルスの間隔は 1 刃送り量に相当する. そしてそれぞれのパ ルスのピークの高さが熱電対からのその距離における温度で ある. したがって, もし高速切削に対応した過渡的な温度測 定が行えているならば, それぞれのパルスのピーク位置で切 れ刃が熱電対からどれだけの距離にあるかを求めると, 切れ 刃が熱電対に近づいて切断するまで切削熱に依存した温度分 布が求まり, それから正確な切削温度を求めることができる

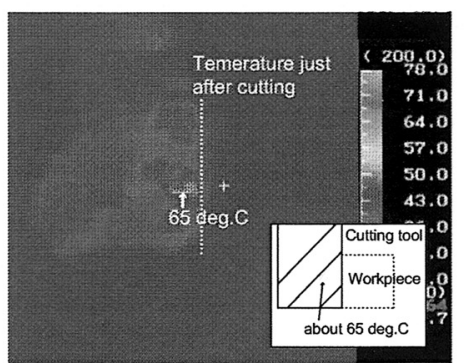

Fig.6 Cutting edge temperature distribution with thermography Cutting speed: $31.4 \mathrm{~m} / \mathrm{min}$, Feed per tooth: $0.125 \mathrm{~mm} /$ tooth, Radial depth of cut: $1 \mathrm{~mm}$, Axial depth of cut: $5 \mathrm{~mm}$, Cutting tool: 2 flutes square endmill $\phi 10$, Down cutting

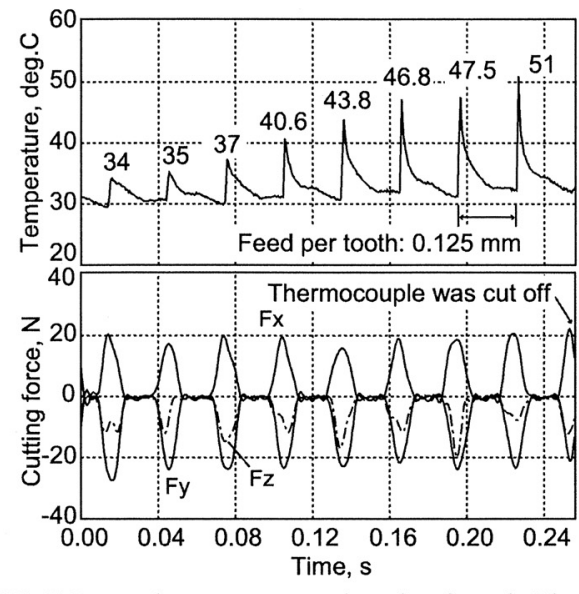

Fig.7 Internal temperature and cutting force in Fig.6

はずである.

しかしながら，皮質骨の熱伝導率が低いことや，熱電対先 端の熱容量が大きいことを考慮すると，厳密に過渡的温度測 定が行えていたとは考えられず, 試験片内部の温度は単に切 削熱に影響された内部温度という表現しかできないし，熱電 対と工具切れ刃との距離がゼロのところを切削温度と断定す るにも多少の無理があるということになる．ところが，その 一方で定性的には，この熱電対と切れ刃の距離がゼ口のとこ ろで実際の切削温度に近い值が測定できるであろうと推定も できるので, 本研究ではこの温度を切削温度と仮定して以下 の議論を進めることにした.

\section{2 上向き切削と下向き切削の切削温度}

図 8 は上向き切削と下向き切削における試験片表面下の温 度分布を示している. この図で, $1_{4}$ は熱電対が切断される直 前の切れ刃と熱電対の距離である. 同様に, $1_{3}$ は熱電対から 2 枚前の, $1_{2}$ は熱電対から 3 枚前の切れ刃と熱電対の距離で ある. 例えば上向き切削の例をみると，熱電対に最も近づい た $1_{4}$ の距離が約 $12.5 \mu \mathrm{m}$ でそのときの温度は約 $73{ }^{\circ} \mathrm{C}$ であ る. そして熱電対から $125 \mu \mathrm{m}$ 離れていた 3 枚前の切れ刃の $1_{3}$ のところでは約 $40^{\circ} \mathrm{C}$ である. さらに 4 枚前の切れ刃のと きに熱電対が測定する温度は実験開始の室温である.つまり 熱電対から $200 \mu \mathrm{m}$ も離れると切削温度は伝わっていないこ とが分かる.

また，上向き切削と下向き切削の切削温度を比較すると， 明らかに上向き切削の温度が高い.このグラフから熱電対で の温度を推定してみると, 上向き切削で約 $78{ }^{\circ} \mathrm{C}$, 下向き切 削で約 $58^{\circ} \mathrm{C}$ であり，その差は $20^{\circ} \mathrm{C}$ になる.

この上向き切削と下向き切削の切削温度の違いをサーモグ ラフで比較してみると, 図 9(a)(b) のようになり, サーモグラ フでも上向き切削の温度が高いことが分かる.

金属のフライス加工では, 上向き切削のとき切れ刃前方に 切削熱が蓄積されるので刃先温度が上がりやすくなるといわ れている.これに対して骨の場合，前述の表 1 でも分かるよ うに，熱伝導率が金属の約 $1 / 100$ であるために熱が拡散しに くく蓄熱効果が一層大きくなることが影響していると考えら れる. そしてこれに加えて, 上向き切削では切削開始点での 切れ刃の上滑りによる摩擦温度の上昇も考えられる. その反 対に下向き切削では, 切れ刃の切削が進むにつれて切りくず 厚さが減少し, 切りくずが刃先より離脱しやすくなるし, 切 削終了点での切れ刃の上滑りの影響が少なく, 切れ刃に対す 


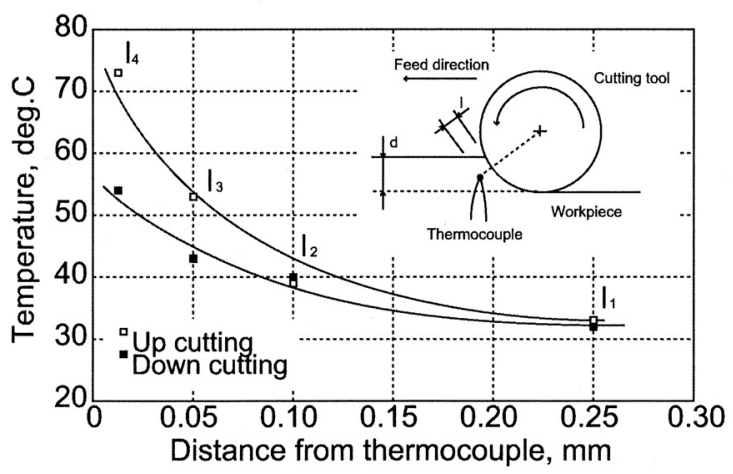

Fig.8 Internal temperature distribution in up and down cutting Cutting speed: $31.4 \mathrm{~m} / \mathrm{min}$, Feed per tooh: $0.375 \mathrm{~mm} /$ tooth, Radial depth of cut: $1 \mathrm{~mm}$, Axial depth of cut: $5 \mathrm{~mm}$, Cutting tool: 2 flutes square endmill $\phi 10$, Down cutting

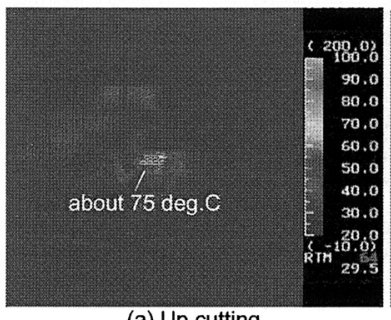

(a) Up cutting

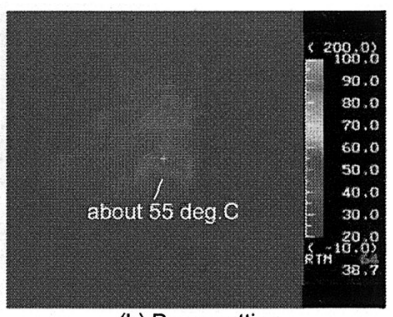

(b) Down cutting
Fig.9 Comparison with up and down cutting on thermograph Cutting speed: $31.4 \mathrm{~m} / \mathrm{min}$, Feed per tooh: $0.25 \mathrm{~mm} / \mathrm{tooth}$, Radial depth of cut: $1 \mathrm{~mm}$, Axial depth of cut: $5 \mathrm{~mm}$, Cutting tool: 2 flutes square endmill $\phi 10$

る切削熱の影響は上向き切削の場合よりも軽度であると考え られるので, 基本的には, 皮質骨の場合も金属の場合と同様 のことが言えるようである.

\section{3 切削速度の影響}

図 10 は切削速度と切削抵抗および切削温度との関係を示 したものである. 図に示すように, 切削速度が $7.85 \mathrm{~m} / \mathrm{min}$ か ら $62.8 \mathrm{~m} / \mathrm{min}$ の間で約 $10^{\circ} \mathrm{C}$ の温度上昇にとどまり, 切削速 度が切削温度に及ぼす影響は小さいとみられる.これに対し て, 細川ら ${ }^{6)}$ にると, 鋼のエンドミル加工では切削速度が $50 \mathrm{~m} / \mathrm{min}$ から $600 \mathrm{~m} / \mathrm{min}$ の間で数百度の温度上昇が測定され ている. 被削材も切削条件も異なるので正当な比較はできな いが, 切削速度が $52.2 \mathrm{~m} / \mathrm{min}$ で 1 刃送り量 $0.047 \mathrm{~mm} /$ tooth, 半径方向切込 $0.2 \mathrm{~mm}$, 軸方向切込 $10 \mathrm{~mm}$ のとき切削温度は $340{ }^{\circ} \mathrm{C}$ であったのに対して, 筆者が測定した皮質骨の例で は, 切削速度が $62.8 \mathrm{~m} / \mathrm{min}$ で 1 刃送り量 $0.125 \mathrm{~mm} /$ tooth, 半 径方向切込 $1 \mathrm{~mm}$, 軸方向切込 $5 \mathrm{~mm}$ のときの切削温度は約 $56{ }^{\circ} \mathrm{C}$ であった.

骨の切削温度が金属に比べて低いのは, 皮質骨の切削抵抗 が低く鋼のおよそ 1/10～1/20であることから考えて，切削エ

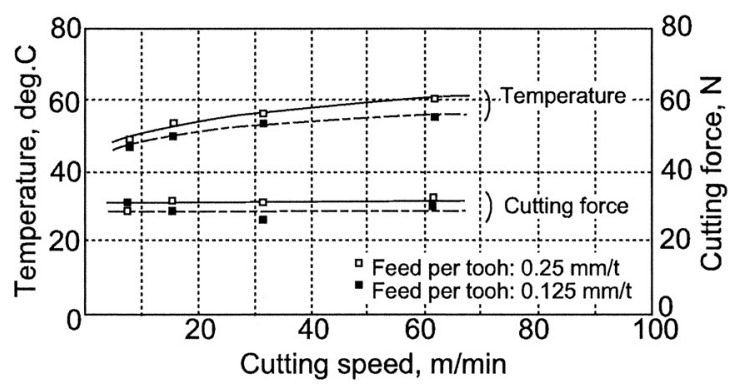

Fig.10 Influence of cutting speed in cutting temperature and force Axial depth of cut: $5 \mathrm{~mm}$, Radial depth of cut: $1 \mathrm{~mm}$, Down cutting, Cutting tool: 2 flutes square endmill $\phi 10$

\section{ネルギーが低かったためと考えられる.}

また, 切削速度によって切削抵抗はほとんど変化しない. 図 10 からも分かるように, 切削速度を 10 倍近く上げても切 削温度の上昇はわずかに $10^{\circ} \mathrm{C}$ 程度にとどまることから, そ の程度の切削温度上昇が切削抵抗を変えるほどの材料物性の 変化をもたらさなかったためと考えられる。

ただし, 切削温度がわずかに $10^{\circ} \mathrm{C}$ 上昇しても骨組織に悪 影響をもたらす温度領域ならば, 骨組織や細胞を破壊する可 能性があるので, 後述するような切削環境の冷却を考慮する 必要がある.

\subsection{1 刃送り量の影響}

図 11 は切削温度に対する 1 刃送り量の影響を示す. 切削 抵抗は上向き切削も下向き切削もほとんど差異はないのに, 図 8 でも述べたように, 上向き切削の切削温度は高くなる. 上向き切削と下向き切削の温度差は $10 \sim 15{ }^{\circ} \mathrm{C}$ である. ま た, 切削温度は 1 刃送り量とともに若干高くなるが, 1 刃送 り量が $0.015 〜 0.35 \mathrm{~mm} /$ tooth の範囲での温度上昇はわずかに 5〜 $10{ }^{\circ} \mathrm{C}$ にすぎない. したがって, 切削温度における 1 刃送 り量の影響もさほどに大きなものではないといえる. ところ が図 11 によると, この 1 刃送り量の範囲で切削抵抗の差異 はほぼ 2 倍に達している. つまりこの切削抵抗の違いがほと んど切削温度に影響していないのである. これについては次 のように考えることができる.

筆者らが別に行った豚皮質骨の 2 次元切削における切り取

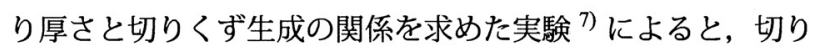
取り厚さが小から大に変化するにつれて切りくず生成形態が 大きく異なる. それによると, 切取り厚さが $0.01 \mathrm{~mm}(10 \mu \mathrm{m})$ では塑性変形を伴った連続流れ型切りくずを生成し, 0.03 $\mathrm{mm}(30 \mu \mathrm{m})$ では流れ型切りくずとなるがその中に多数の微 小な脆性亀裂を含む. また $0.1 \mathrm{~mm}(100 \mu \mathrm{m})$ に近づくと明瞭 な脆性破壊で不連続なブロック状の切りくずを生成し，亀裂 間で塑性変形の痕跡は観察されなかった.

この現象をエンドミル切削に当てはめてみると次のように なる. 例えば下向き切削で 1 刃送り量を $0.1 \mathrm{~mm}$ にとると, 切 れ刃が切削開始点で被削材に衝突したとき, その時点での切 取り量が大きいので, 切れ刃前方の切削進行方向に脆性亀裂 が断熱的に発生すると考えられる. そのために, 切れ刃の切 取り量が大きいにもかかわらず切削温度上昇に関与しなかっ たとみられる. このことは切取り量が少なくても切りくずに 脆性亀裂を含む場合にもあてはまると考えられる. そして切 れ刃による切削が進行し, 切取り量が少なくなって切りくず 生成が延性的になってくると, 切削熱の発生が顕著になって くる. このような解釈が成り立つとすれば, 1 刃送り量が 0.1

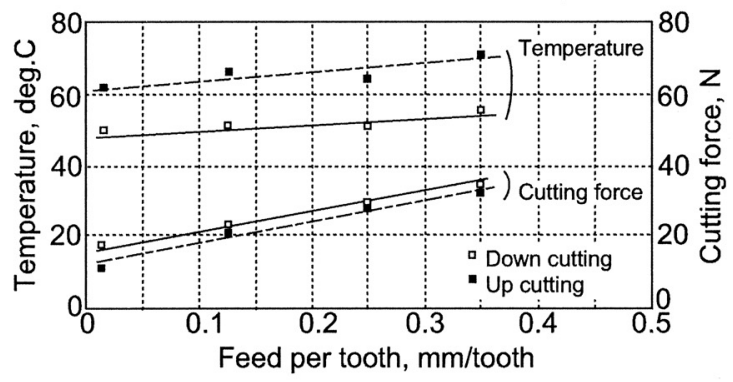

Fig.11 Influence of feed per tooth in cutting temperature and force Cutting speed: $31.4 \mathrm{~m} / \mathrm{min}$, Radial depth of cut: $1 \mathrm{~mm}$, Axial depth of cut: $5 \mathrm{~mm}$, Cutting tool: 2 flutes square endmill $\phi 10$ 
$\mathrm{mm} /$ tooth 以上では切削温度が工具送り量に大きく依存しない とみてよいのではなかろうか.

\section{5 切削環境の冷却効果}

切削環境を冷却することが切削温度の低減にどのような効 果を発揮するかを知るために，前述のように工具および試験 片を装置に取り付けた状態で, ドライアイスを直接押し付け る方法で冷却し, 実験開始温度に達した後に実験した. 冷却 方法としては, ドライアイスを用いる乾式と冷却水を用いる 湿式が考えられるが, 冷却温度の制御性から本実験ではドラ イアイスを用いた．このときの切削条件は, 切削速度 31.4 $\mathrm{m} / \mathrm{min}, 1$ 刃送り量 $0.25 \mathrm{~mm} /$ tooth, 半径方向切込 $1 \mathrm{~mm}$, 軸方 向切込 $5 \mathrm{~mm}$ である.

まず，工具か骨だけ単独あるいは両者同時に $-5{ }^{\circ} \mathrm{C}$ に冷却 したときの工具刃先温度をサーモグラフィーで観測した結果 を図 12 に示す. 同じ条件で常温切削を行った図 9 と比較す ると, 冷却効果が認められる. しかしながら, このサーモグ ラフの結果だけで切削温度を推定するのは困難なので, 熱電 対法による温度分布測定からも推定することとした。

図 13 は各種の冷却状態の工具と骨を用いた切削におけ る試験片内部の温度分布を示す. 骨と工具の初期温度が 30 ${ }^{\circ} \mathrm{C}$ (室温) の場合に比べると, 工具を $0{ }^{\circ} \mathrm{C}$ まで冷却するだけ で, 切削温度を約 $5{ }^{\circ} \mathrm{C}$ 下げることができる. しかし, 切削温 度が $52^{\circ} \mathrm{C}$ の温度から $47^{\circ} \mathrm{C}$ に低下しただけであり, その温 度では骨細胞が熱的損傷を受ける可能性が高い. そこで工具 を $-5{ }^{\circ} \mathrm{C}$ に冷却すると，切削温度は $38^{\circ} \mathrm{C}$ にまで低下した.

これに対して, 骨を $0{ }^{\circ} \mathrm{C}$ に冷却しても $-5^{\circ} \mathrm{C}$ に冷却しても
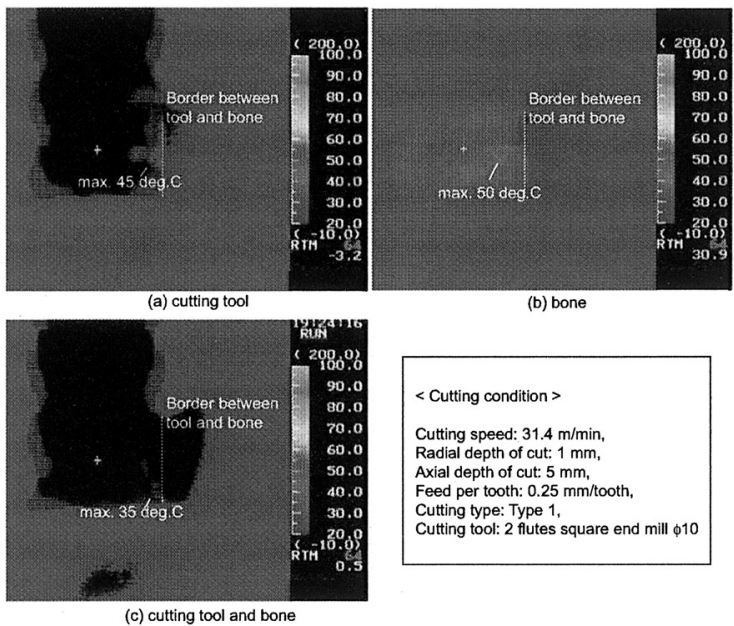

(c) culting tool and bone

Fig.12 Temperature of cutting edge using cutting tool and bone cooled at $-5 \operatorname{deg} . \mathrm{C}$

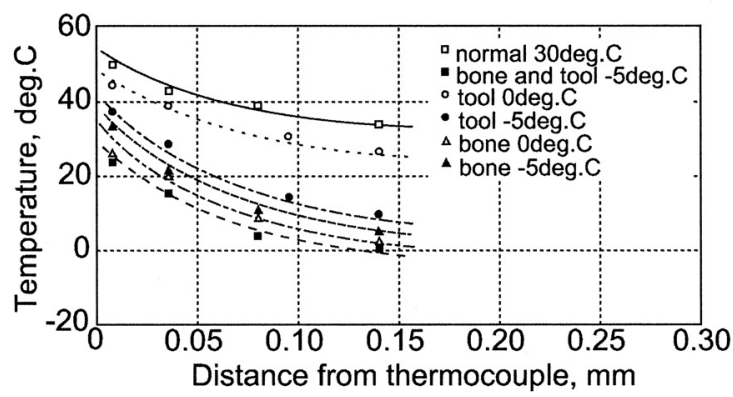

Fig.13 Internal temperature distribution in several cooling environments Cutting speed: $31.4 \mathrm{~m} / \mathrm{min}$, Radial depth of cut: $1 \mathrm{~mm}$, Axial depth of cut: $5 \mathrm{~mm}$, Feed per tooth: $0.25 \mathrm{~mm} / \mathrm{tooth}$, Cutting tool: 2 flutes square endmill $\phi 10$
その冷却効果はあまり変わらないが, 工具のみを冷却する場 合よりも冷却効果は大きく, 切削温度は $30 \sim 35^{\circ} \mathrm{C}$ にまで低 下する.これは骨の熱伝導率が低く，蓄熱効果も大きいので 骨の冷却作用が優れているためと考えられる.

次に工具と骨の双方を同時に- $5 \circ$ に冷却すると, 切削温度 は $27^{\circ} \mathrm{C}$ にまで低下する. 同様に工具と骨を $0{ }^{\circ} \mathrm{C}$ に冷却し

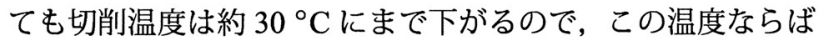
切削熱に起因した骨細胞の壊死を防止できる.

しかしながら, 上述のような切削環境冷却法をそのまま人 工関節置換部に適用すると生体凍傷を生ずる恐れがあるの で, 実際の手術では生体冷却損傷を回避できる温度の冷却水 による冷却を考慮する必要がある。

\section{5. 結 論}

以上の結果をまとめると次のようになる.

（1）上向き切削では，その切削形態に依存した蓄熱作用や 上滑りによる摩擦のために下向き切削よりも温度上昇 を招きやすい.

(2) 切削速度が $7.85 \mathrm{~m} / \mathrm{min}$ から $62.8 \mathrm{~m} / \mathrm{min}$ の間での温度 上昇は約 $10^{\circ} \mathrm{C}$ である.これに対して切削抵抗はほと んど変化しない.つまりこの切削温度上昇が材料物性 を変えるほどのものではないので, 切削抵抗は変化し なかったと考えられる.

(3) 1 刃送り量が $0.015 \sim 0.35 \mathrm{~mm} /$ tooth の間での温度上昇

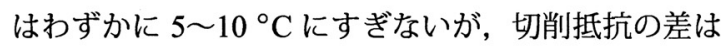
約 2 倍にも達し, 切削抵抗の違いが切削温度に影響し ていない. これは 1 刃送り量が大きく, 切れ刃の切り 取り厚さが大きいと脆性亀裂を生ずるが, それが切削 温度の上昇にほとんど関与しないためと考えられる.

(4) 工具と骨の双方を冷却すると大きな冷却効果が期待で きる. 例えば- $5{ }^{\circ} \mathrm{C}$ に冷却すれば切削温度は $27^{\circ} \mathrm{C} に$ なり, 切削熱による骨細胞の壊死を回避できる. しか し生体の冷却損傷に配慮しなければならない.

\section{謝辞}

本研究の一部は, 文部科学省科学研究費補助金 (若手研究 (B) 課題番号 16760085) の助成を受けて行ったもので, ここ に謝意を表する.

\section{参 考 文 献}

1) M.Mitsuishi, et al., Development of a 9 Axes Machine Tool for Bone Cutting, Annals of the CIRP, 52/1 (2003) 323.

2) W.R.Krause, Orthogonal Bone Cutting: Saw Design and Operating Characteristics, Journal of Biomechanical Engineering, 109 (1987) 263.

3) A.Finch and D.A.Ledward, Shrinkage of collagen fibres;A differential scanning calorimetric study, Biochim. Biophys. Acta, 278 (1972) 433.

4) A.Malvisi, P.Vendruscolo, F.Morici and M.Marcacci, Milling versus Sawing: Comparison of Temperature Elevation and Clinical Performance During Bone Cutting, MICCAI2000, LNCS1935 (2000) 1238.

5) S.Biyikli, M.F.Modest and R.Tarr, Measurements of thermal properties for human femora, J.Biomedical Materials Res., 20/9 (1986) 1335.

6) 細川晃, 小田健作, 山田啓司, 上田隆司, 断続切削における工具逃げ 面温度 -高速エンドミル加工に関する研究 (第 1 報), 精密工学会 誌, 66/11 (2000) 1786.

7) 杉田忠彰, 舟田義則, 杉田直彦, 粟津薰, 光石衛, 豚皮質骨の切削挙 動について (第 2 報) - 切削条件と組織異方性の影響 -, 先端加工学 会誌, 23/1 (2005) 58 . 